\title{
Dry Matter Production and Distribution in three Cassava (Manihot esculenta Crantz) Cultivars During the Second Vegetative Plant Cycle
}

\author{
Edvaldo Sagrilo $^{1 *}$, Pedro Soares Vidigal Filho ${ }^{2}$, Manoel Genildo Pequeno ${ }^{2}$, Maria Celeste \\ Gonçalves-Vidigal $^{2}$ and Marcus Vinícius Kvitschal ${ }^{3}$ \\ Embrapa Meio-Norte; Av. Duque de Caxias, 5650; Bairro Buenos Aires; C.P.: 001; sagrilo@cpamn.embrapa.br; \\ 64006-220; Teresina - PI - Brasil. ${ }^{2}$ Departamento de Agronomia; Universidade Estadual de Maringá; Av. \\ Colombo, 5790; psvfilho@uem.br; 87020-570; Maringá - PR - Brasil. ${ }^{3}$ Programa de Pós-Graduação em Genética e \\ Melhoramento; Universidade Estadual de Maringá; Av. Colombo, 5790; marcusvk78@hotmail.com; 87020-570; \\ Maringá - PR - Brasil
}

\begin{abstract}
A study was carried out in Araruna County, State of Paraná, to understand the relationship between the total dry matter yield and its proportion allocated to the storage roots of cassava (Manihot esculenta Crantz) plants in the second vegetative cycle. The experimental design was a randomized complete block in split-plot scheme with four replications. The plots consisted of the Mico, IAC 13 and IAC 14 cultivars and the monthly harvesting dates were assessed in the sub-plots. The results showed that the Mico and IAC 13 cultivars were more efficient in allocating dry matter to the storage roots. The IAC 14 cultivar allocated a higher proportion of assimilates to stems compared with the other two cultivars. With regard to the influence of harvesting time, the lowest harvest indexes were observed in the periods of more intense vegetative growth. However, the highest carbohydrate proportions were allocated to the storage roots during periods of low vegetative growth.
\end{abstract}

Key words: Harvesting time; dry matter allocation; harvest index

\section{INTRODUCTION}

Cassava (Manihot esculenta Crantz) is a shrub species which belongs to the Euforbiacea family that grows continuously, with alternating plant growth periods and carbohydrate storage in its tuberous roots followed by periods of dormancy (Alves, 2002). It is native from Brazil, according to philogeographic studies by Olsen and Schaal (1999), and it is exploited as one of the main foodstuffs of the populations in the tropical regions, because its storage roots are rich in starch. In the production systems where it is cultivated, cassava can be characterized as subsistence (Africa), economic (Thailand and China) or ethnic and cultural species (Brazil and other countries in South America) (Cereda, 2002). Although its ethnic and cultural values are strongly characterized in Brazil, cassava also plays an important role in community survival, especially in the North and Northeast regions (Cardoso and Souza, 2002), and is an important source of raw material for many industrialized agricultural products (Conceição, 1981; Doretto, 1993).

Storage root production for agro-industrial use is of great importance in the Central Southern region

\footnotetext{
* Author for correspondence
} 
of Brazil, especially in the states of São Paulo, Mato Grosso do Sul and Paraná (Cardoso and Souza, 2002) and currently accounts for $64.7 \%$ of Brazilian starch production (Abam, 2006). In Paraná, the development of the cassava industrial sector has created continuous technological demands. These demands are related to improving the cropping practices, including the recommendation of new cultivars and rational management, such as a better definition of harvest time and possible interactions among such factors. All these technological demands are intended to increase the yield and to widen the period of storage roots and its use, hence, the functioning of the industries.

Souza and Fasiaben (1986) observed that the cultivars Palma-de-Umuarama, Branca-de-Santa Catarina, IAC 12, Amarela-da-Fruticultura, Palma and Mico have the highest yield capacity for the conditions of Rio Azul, Paraná. Vidigal Filho et al. (2000) showed the potential of the cultivars Fécula Branca, IAC 14 and Mico for high storage root yield and tolerance to bacterial blight caused by Xanthomonas axonopodis pv. manihotis in Araruna, Northwest of Paraná. Rimoldi et al. (2003) highlighted the productive potential of the clones IAC 45-85, IAC 163-85 and IAC 321-85 for the conditions of Maringá and Rolândia, Paraná. Kvitschal (2006) reported high yield and high phenotypic stability in the clone IAC 190 in the studies carried out in Araruna and Maringá. Kvitschal et al. (2003b) also observed the production potential of the clone IAC 46- 90 in Araruna and Maringá.

Rimoldi et al. (2006) found that the traditional cultivars Caipira, Branca 1, Amarela 1, Amarela 2 and Fécula Branca showed high roots yields and starch contents, a good and regular cooking time, low HCN content, and also tolerance to the bacterial blight. Furthermore, Sagrilo et al. (2002) assessed the performance of cassava cultivars in the Northwest Paraná at different harvest times and concluded that, for those conditions, the physiological rest period at the end of the second crop cycle was more indicated for harvest, due to the higher production of the storage root fresh and dry matter and starch. Sagrilo et al. (2003) observed that the cultivars IAC 13, IAC 14 and Fécula Branca had high dry matter content in the storage roots. They also emphasized the importance of selecting the genotypes which had high dry matter content in the storage roots, to obtain better yield.

However, there are only few studies that explain the performance of cassava cultivars regarding their biological production (total dry biomass) and its relationship with the efficiency in the storage root dry matter accumulation at different harvesting times.

Thus, the objective of the present work was to study the performance of the total biomass production and its partitioning on different portions of the plant in three cassava cultivars during the second vegetative cycle.

\section{MATERIAL AND METHODS}

The experiment was carried out under field conditions in the County of Araruna, Northwest of Paraná $\left(23^{\circ} 55^{\prime} \mathrm{S}\right.$ and 52 $\left.30^{\prime} \mathrm{O}\right)$ from October 1997 to March 1999, in a dystrophic red latossol (Embrapa, 1999) in an area of Pinduca - Indústria Alimentícia Ltda. Chemical characteristics of the $0-0.20 \mathrm{~m}$ layer in the experimental area were: $\mathrm{pH}$ $\left(\mathrm{CaCl}_{2}\right)$ 5.2; $\mathrm{pH}$ (water) 6.4; $\mathrm{Al}^{3+}\left(\mathrm{cmol}_{\mathrm{c}} \mathrm{dm}^{-3}\right)$ $0.00 ; \mathrm{H}^{+}+\mathrm{Al}^{3+}\left(\mathrm{cmol}_{\mathrm{c}} \mathrm{dm}^{-3}\right)$ 3.17; $\mathrm{Ca}^{2+}+\mathrm{Mg}^{2+}$ $\left(\mathrm{cmol}_{\mathrm{c}} \mathrm{dm}^{-3}\right)$ 2.44; $\mathrm{Ca}^{2+}\left(\mathrm{cmol}_{\mathrm{c}} \mathrm{dm}^{-3}\right) 1.49 ; \mathrm{K}^{+}$ $\left(\mathrm{cmol}_{\mathrm{c}} \mathrm{dm}^{-3}\right)$ 0.32; $\mathrm{P}\left(\mathrm{mg} \mathrm{dm}^{-3}\right) 5.0$ and $\mathrm{C}\left(\mathrm{g} \mathrm{dm}^{-3}\right)$ 13.57 .

The climate in Araruna is classified as $\mathrm{Cfb}$, according to Köppen, with a $21.5^{\circ} \mathrm{C}$ mean annual temperature, 1,617 $\mathrm{mm}$ mean annual rainfall and $62 \%$ mean annual relative humidity (Godoy et al., 1976). Fig. 1 shows the data for maximum and minimum temperatures and rainfall observed during the experimental period.

The cassava cultivars Mico, IAC 13 and IAC 14 were used. The first was collected in Paraná and the others came from the Experimental Cassava Field at the Campinas Agronomic Institute (IAC). The three cultivars, recommended for cropping in Paraná (Vidigal Filho et al., 2000), were monthly harvested during ten dates, starting when the plants had 12 months (first rest period). The experimental design was a randomized complete block, in a split-plot scheme, with four replications. The cultivars were allocated in the plots and harvesting times in the sub-plots. The primary treatments (cultivars) and secondary treatments (harvesting time) were randomized in the blocks and plots, respectively. 


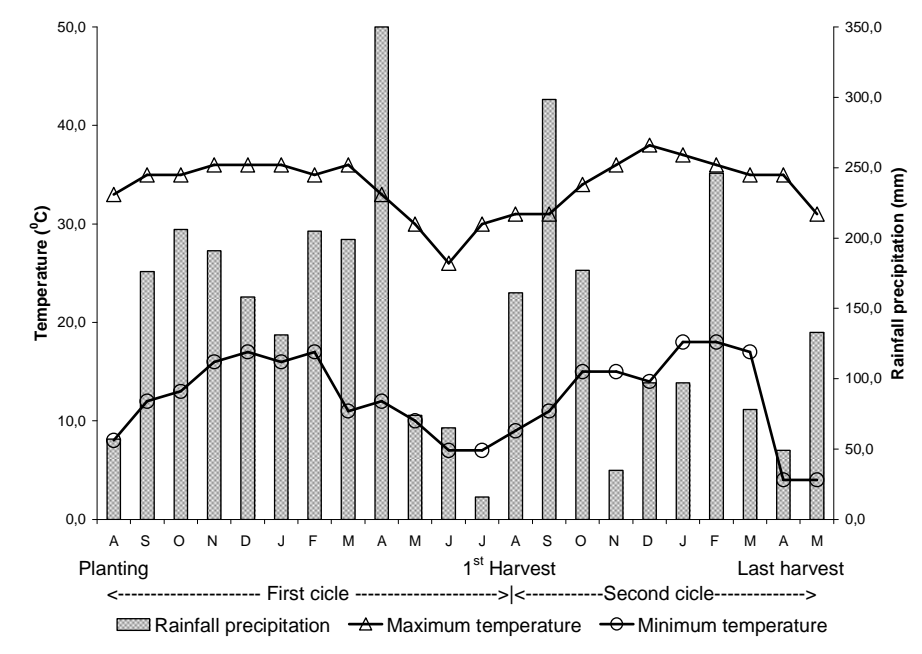

Figure 1 - Mean monthly rainfall, maximum and minimum temperature values observed from August 1997 to May 1999 in Araruna, PR.

The plots were $17.6 \mathrm{~m}$ long and $22.0 \mathrm{~m}$ wide, with row spacing of $1.0 \mathrm{~m}$ and $0.8 \mathrm{~m}$ between the plants in the rows. The total area of each plot was 387.2 $\mathrm{m}^{2}$, with 10 subdivisions for different harvest times, each consisting of a row with 22 plants, separated by the rows of adjacent plants. The plants at the sub-plot boundaries were discarded that resulted in a useful area of $16.0 \mathrm{~m}^{2}$ with 20 plants. Six representative plants were randomly selected from the useful area (Veltkamp, 1985) that were harvested monthly starting in August 1998. Sampled plants were separated into leaves (petiole and blade), stems and storage roots. Later, a sample was taken with a mass of $60 \mathrm{~g}$ of each fraction, and the storage roots and stem samples were further cut into $0.01 \mathrm{~m}$ cubes and dried in a forced circulation chamber at $60^{\circ} \mathrm{C}$ (Sales Filho, 1980). The leaves were dried at $45^{\circ} \mathrm{C}$ (Silva, 1981) to obtain the dry matter content. After drying to constant weight, the yield per area $\left(\mathrm{Mg} \mathrm{ha}^{-1}\right)$ of each fraction was determined.

Data was submitted to the analysis of variance for the main effects (cultivars and harvest time) and for the interaction (cultivars $\mathrm{x}$ harvest times).

When the interaction was significant, the partitioning was performed according to Banzatto and Kronka (1995). Cultivar means were compared by the Tukey test $(\mathrm{P} \leq 0.05)$, while the harvest time data were explained, when possible, by polynomial regression equations.

\section{RESULTS AND DISCUSSION}

Total dry matter distribution and the plant fractions of the Mico, IAC 13 and IAC 14 cultivars are shown in Figs. 2, 3, and 4, respectively. Dry matter referred to the leaves that were retained on the plant, stems and storage roots. Leaf dry matter yield, for all the cultivars, presented a quadratic performance, with higher values occurring in the periods of high temperatures (November to February, Fig. 1) and almost total leaf loss in the low temperature periods. Variation in cassava leaf yield as a function of the climate has been reported by several authors, but Távora and Barbosa Filho (1994) emphasized that the quantity of the leaves was determined by the plant age and that the variation in climatic conditions, especially temperature, could only accelerate or delay this process.

The harvest in December, when cassava cultivars had 16 months, resulted in high leaf dry matter yield, a period when this yield represented $12.39 \%$ of the total dry matter yield for the Mico, $10.56 \%$ for IAC 13 and $8.72 \%$ for IAC 14. Significant differences were observed only when the plants had 17 and 18 months and at these harvest times, Mico and IAC 14 were better than IAC 13. 


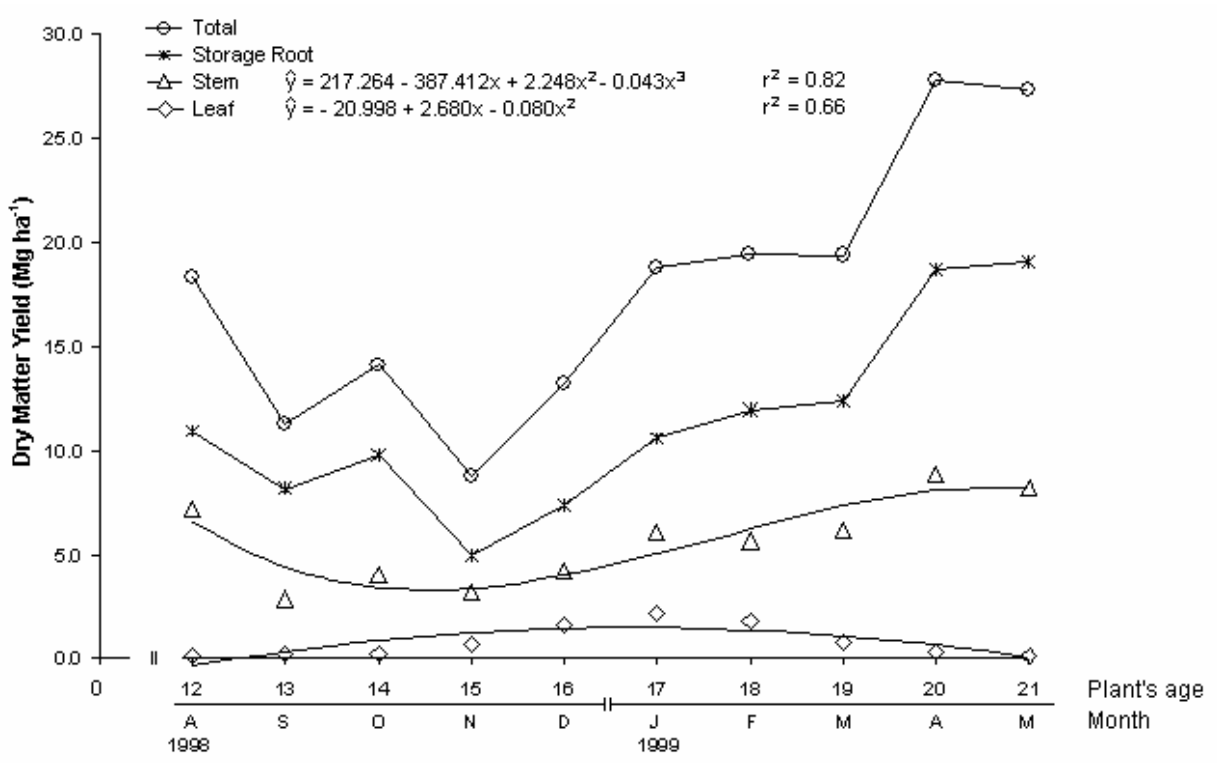

Figure 2 - Leaf, stem, storage root and total dry matter yield $\left(\mathrm{Mg} \mathrm{ha}^{-1}\right)$ of the storage roots for cassava cultivar Mico at 10 harvest dates during the second vegetative cycle. Araruna, PR, 1998/99.

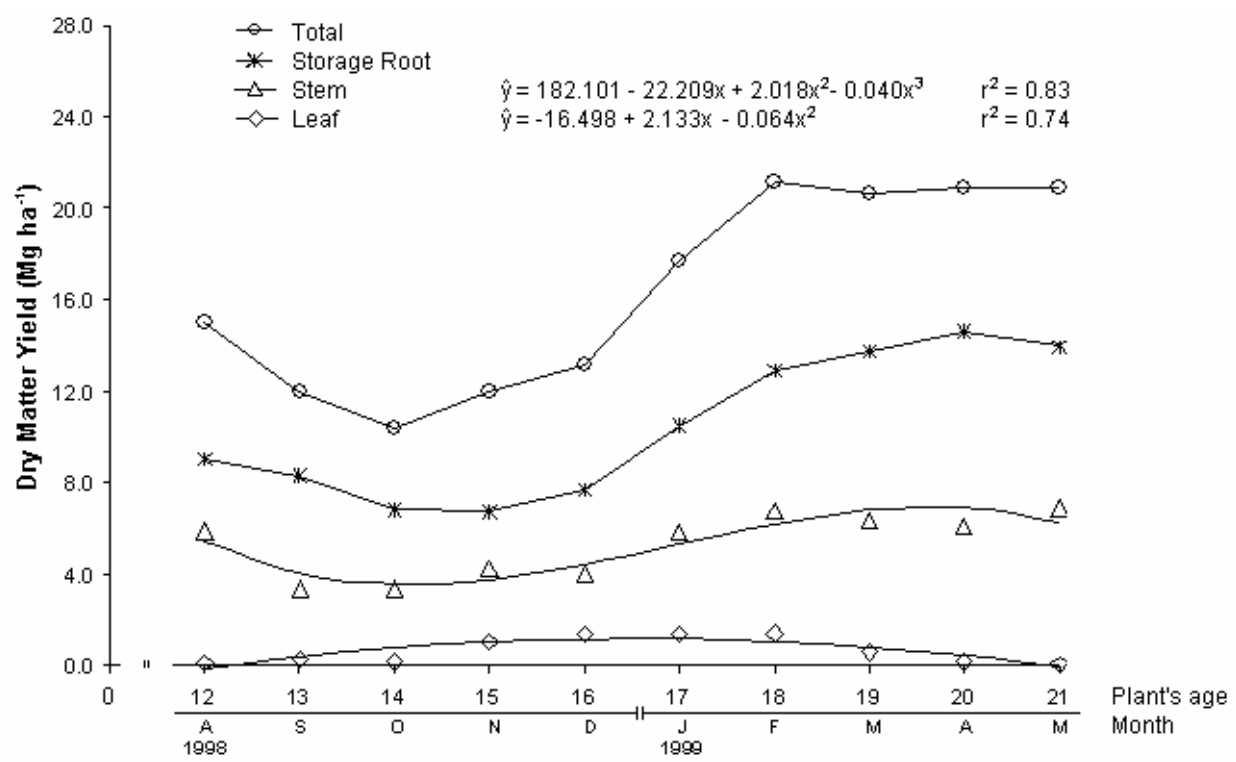

Figure 3 - Leaf, stem, storage root and total dry matter yield $\left(\mathrm{Mg} \mathrm{ha}^{-1}\right)$ of the storage roots for cassava cultivars IAC 13 at 10 harvest dates during the second vegetative cycle. Araruna, PR, 1998/99. 


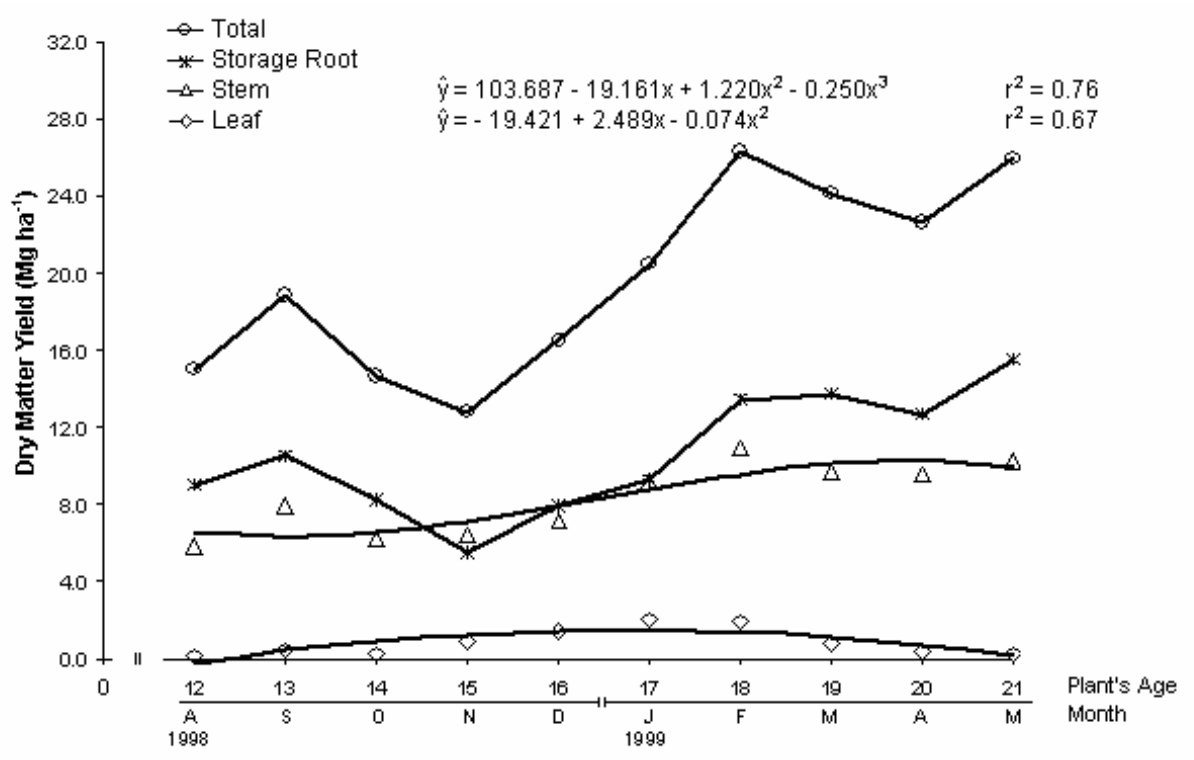

Figure 4 - Leaf, stem, storage root and total dry matter yield $\left(\mathrm{Mg} \mathrm{ha}^{-1}\right)$ of the storage roots for cassava cultivar IAC 14 at 10 harvest dates during the second vegetative cycle. Araruna, PR, 1998/99.

Table 1 - Means of leaf dry matter production $\left(\mathrm{Mg} \mathrm{ha}^{-1}\right)$ for three cassava cultivars at 10 harvest dates during the second vegetative cycle. Araruna, PR, 1998/99.

\begin{tabular}{|c|c|c|c|c|c|c|c|c|c|c|}
\hline \multirow{3}{*}{ Cultivars } & \multicolumn{10}{|c|}{ Leaf dry matter production $\left(\mathrm{Mg} \mathrm{ha}^{-1}\right)$} \\
\hline & \multicolumn{10}{|c|}{ Plant's age (month) } \\
\hline & 12 (Aug) & 13 (Sep) & $14(\mathrm{Oct})$ & 15 (Nov) & 16 (Dec) & 17 (Jan) & $18(\mathrm{Feb})$ & 19 (Mar) & 20 (Apr) & 21 (May) \\
\hline Mico & $0.146 \mathrm{a}$ & $0.220 \mathrm{a}$ & $0.248 \mathrm{a}$ & $0.699 \mathrm{a}$ & $1.643 \mathrm{a}$ & $2.168 \mathrm{a}$ & $1.814 \mathrm{a}$ & $0.820 \mathrm{a}$ & $0.335 \mathrm{a}$ & $0.130 \mathrm{a}$ \\
\hline IAC 13 & $0.118 \mathrm{a}$ & $0.299 \mathrm{a}$ & $0.173 \mathrm{a}$ & $1.017 \mathrm{a}$ & $1.388 \mathrm{a}$ & $1.364 \mathrm{~b}$ & $1.408 \mathrm{~b}$ & $0.580 \mathrm{a}$ & $0.162 \mathrm{a}$ & $0.072 \mathrm{a}$ \\
\hline IAC 14 & $0.120 \mathrm{a}$ & $0.426 \mathrm{a}$ & $0.245 \mathrm{a}$ & $0.900 \mathrm{a}$ & $1.441 \mathrm{a}$ & $2.017 \mathrm{a}$ & $1.902 \mathrm{a}$ & $0.763 \mathrm{a}$ & $0.379 \mathrm{a}$ & $0.222 \mathrm{a}$ \\
\hline $\mathrm{F}$ & $0.02^{\mathrm{ns}}$ & $0.77^{\mathrm{ns}}$ & $0.13^{\mathrm{ns}}$ & $1.85^{\mathrm{ns}}$ & $1.28^{\mathrm{ns}}$ & $12.98 *$ & $4.44 *$ & $1.11^{\mathrm{ns}}$ & $0.94^{\mathrm{ns}}$ & $0.40^{\mathrm{ns}}$ \\
\hline
\end{tabular}

* Significant at $5 \%$ probability based on $\mathrm{F}$ test; ${ }^{\text {ns }}$ not significant; Means followed by the same letter in the column do not differ from each other, based on the Tukey test $(\mathrm{P} \leq 0,05)$.

Table 2 - Means of stem dry matter production $\left(\mathrm{Mg} \mathrm{ha}^{-1}\right)$ for three cassava cultivars at 10 harvest dates during the second vegetative cycle. Araruna, PR, 1998/99.

\begin{tabular}{|c|c|c|c|c|c|c|c|c|c|c|}
\hline \multirow{3}{*}{ Cultivars } & \multicolumn{10}{|c|}{ Stem dry matter production $\left(\mathrm{Mg} \mathrm{ha}^{-1}\right)$} \\
\hline & \multicolumn{10}{|c|}{ Plant's age (month) } \\
\hline & 12 (Aug) & 13 (Sep) & $14(\mathrm{Oct})$ & 15 (Nov) & $16(\mathrm{Dec})$ & 17 (Jan) & $18(\mathrm{Feb})$ & 19 (Mar) & 20 (Apr) & 21(May) \\
\hline Mico & $7.221 \mathrm{a}$ & $2.854 \mathrm{~b}$ & $4.062 \mathrm{ab}$ & $3.154 \mathrm{~b}$ & $4.242 \mathrm{~b}$ & $6.039 \mathrm{~b}$ & $5.658 \mathrm{~b}$ & $6.164 \mathrm{~b}$ & $8.831 \mathrm{ab}$ & $8.171 \mathrm{ab}$ \\
\hline IAC 13 & $5.868 \mathrm{a}$ & $3.362 \mathrm{~b}$ & $3.352 \mathrm{~b}$ & $4.215 \mathrm{ab}$ & $4.035 \mathrm{~b}$ & $5.860 \mathrm{~b}$ & $6.801 \mathrm{~b}$ & $6.318 \mathrm{~b}$ & $6.110 \mathrm{~b}$ & $6.860 \mathrm{~b}$ \\
\hline IAC 14 & $5.864 \mathrm{a}$ & $7.934 \mathrm{a}$ & $6.190 \mathrm{a}$ & $6.390 \mathrm{a}$ & $7.130 \mathrm{a}$ & $9.182 \mathrm{a}$ & $10.950 \mathrm{a}$ & $9.645 \mathrm{a}$ & $9.574 \mathrm{a}$ & $10.238 \mathrm{a}$ \\
\hline $\mathrm{F}$ & $0.89^{\mathrm{ns}}$ & $11.40^{*}$ & $3.18^{*}$ & $3.96^{*}$ & $4.36^{*}$ & $5.08 *$ & $11.29^{*}$ & $5.63^{*}$ & $4.84 *$ & $4.22 *$ \\
\hline
\end{tabular}

* Significant at 5\% probability based on F test; ${ }^{n}$ not significant; Means followed by the same letter in the column do not differ from each other, based on the Tukey test $(\mathrm{P} \leq 0,05)$. 
Stem dry matter fractions showed a cubic performance for the cultivars Mico (Fig. 2), IAC 13 (Fig. 3) and IAC 14 (Fig. 4). A small decrease in mean values were observed at the start of the second vegetative cycle and was probably due to the re-mobilization of carbohydrates stored in the stems to restructure the plant canopy. Moreover, this period of plant canopy restructuring coincided with the most intense increase in dry leaf matter production. The later growth and stabilization in dry matter yield of the stem resulted in reserve replacement by the photosynthesis apparatus that was already structured, and the approximation of the new physiological rest phase of the plant. Variations in the dry matter proportions in the stems compared to the total productivity were much subtly than those observed in leaf dry matter yield. Striking differences, however, were observed among the cultivars, and the contribution of stem dry matter to the total dry matter of plants was on average $31.6 \%$ for Mico, $32.35 \%$ for IAC 13 and $42.45 \%$ for IAC 14. Regarding the differences observed among the cultivars during the harvest times for the dry matter production of the stem (Table 2), the IAC 14 cultivar was generally superior to the others in all the assessments, except for the first, where no difference was ascertained among the cultivars. These data showed the high canopy production potential of IAC 14 cultivar for the Northwest Paraná environmental conditions. Similar findings were also reported by Vidigal Filho et al. (2000). The variation in the storage root dry matter yield over the harvest times did not allow fitting equations that would properly explain its performance. Generally, means decreased slightly at the beginning of the second vegetative cycle and increased afterwards, reaching the maximum values when the new physiological rest period approached. Figs. 2, 3 and 4 contrast the productive performance of the storage root dry matter for Mico, IAC 13 and IAC 14 cultivars, respectively. Leaf dry matter yield indicated that the initial reduction in the storage root yield coincided exactly with the restructuring period of the plant photosynthesis apparatus and that the later increase and stabilization was probably related to the intensification on assimilate production by the photosynthesis apparatus (Sagrilo et al., 2002).

Generally, for the cultivars under study, the performance of the storage root dry matter yield followed the same yield pattern as the stem dry matter, and the values of the first were always superior to those of the latter. This tendency was not repeated, however, for the IAC 14 cultivar, whose storage root dry matter yield was lower than the stem dry matter yield for some periods (Fig. 4). Although the values of both the fractions decreased at the start of the second vegetative cycle, variations in the stem dry matter yield showed an earlier increase, compared to the storage root dry matter. This suggested that the stem reserve establishment was the priority and that they formed a preferential sink (Sagrilo et al., 2006). No significant differences were observed for the storage root dry matter yield based on the mean values of the harvest times (Table 3).

Table 3 - Mean values of storage roots dry matter yield (RDMY), total dry matter yield (TDMY) and harvest index (HI) based on dry matter (\%) of three cassava cultivars at 10 harvesting times during the second vegetative cycle. Araruna, PR, 1998/99.

\begin{tabular}{lccc}
\hline \multicolumn{1}{c}{ Cultivars } & RDMY & TDMY & HI \\
\cline { 2 - 4 } & \multicolumn{2}{c}{$\left(\mathbf{M g ~ h a}^{-\mathbf{1}}\right)$} & $\mathbf{( \% )}$ \\
\hline Mico & $11.398 \mathrm{a}$ & $17.859 \mathrm{ab}$ & $63.20 \mathrm{a}$ \\
IAC 13 & $10.433 \mathrm{a}$ & $16.369 \mathrm{~b}$ & $63.15 \mathrm{a}$ \\
IAC 14 & $10.589 \mathrm{a}$ & $19.740 \mathrm{a}$ & $53.08 \mathrm{~b}$ \\
\hline $\mathrm{F}$ & $1.34^{\mathrm{ns}}$ & $10.65^{*}$ & $8.93^{*}$ \\
\hline * Significant at 5\% probability by the F test $(\mathrm{P} \leq 0.05) .{ }^{\mathrm{ns}}=$ not significant; Means followed by the same letter in the column do not differ based \\
on Tukey test.
\end{tabular}

Mico and IAC 13 cultivars were more efficient than IAC 14 in allocating the dry matter produced in the storage roots (Figs. 2, 3 and, 4). Table 3 confirmed this statement. Mean values of the dry matter based harvest index were maximum for
Mico and IAC 13 cultivars. IAC 14 showed the lowest values because it presented a more vigorous vegetative growth. This demonstrated its limited capacity to allocate the assimilates to the storage roots, compared to the other cultivars. 
A cassava growth model, described by Cock et al. (1979) assumed that the storage roots received only the assimilated that remained after meeting all the growth needs of the plant canopy, a performance also observed by Keating et al. (1982). It could be inferred that this performance did apply to the cultivars evaluated at the present study and IAC 14, because of its genetic characteristics of great vegetative growth led a higher extent of carbohydrates, firstly to its canopy portion and leaving a relatively small proportion for storage roots. However, although the characteristics inherent to the cultivar might condition a less distribution to the storage roots, as observed for the IAC 14 cultivar, some agronomic practices could, in the short-term, result in potential solutions to improve the storage root dry matter production $\mathrm{x}$ total dry matter production ratio, as mentioned by Keating et al. (1982). For example, in the case of IAC 14, its selection for cultivation on the soils with poor fertility could be a viable alternative to improve this ratio. Hobman et al. (1987) also reported less plant growth in comparatively unfavorable conditions compared to other experiments where it was compensated by the better distribution of assimilates to the storage roots, in detriment to the canopy.

Variations in the harvest index based on the dry matter during the second vegetative cycle did show no interaction among the harvest times and cultivars (Fig. 5). Data did not fit to a model that was suitable for the performance presented by the plants.

The values were high at the start of the second crop cycle, over $60 \%$, and fell sharply at the fourth harvest, when the plants had 15 months. Values increased again only after the sixth harvest, when the plants had 17 months, indicating a good balance of assimilates directed to the storage roots, until the last harvest, with values higher than $65 \%$. The period with the lowest harvest index was in November, December and January. This period corresponded to a high vegetative growth period and leafing of the plants. All these events were conditioned by the high temperatures recorded in this period (Fig. 1).

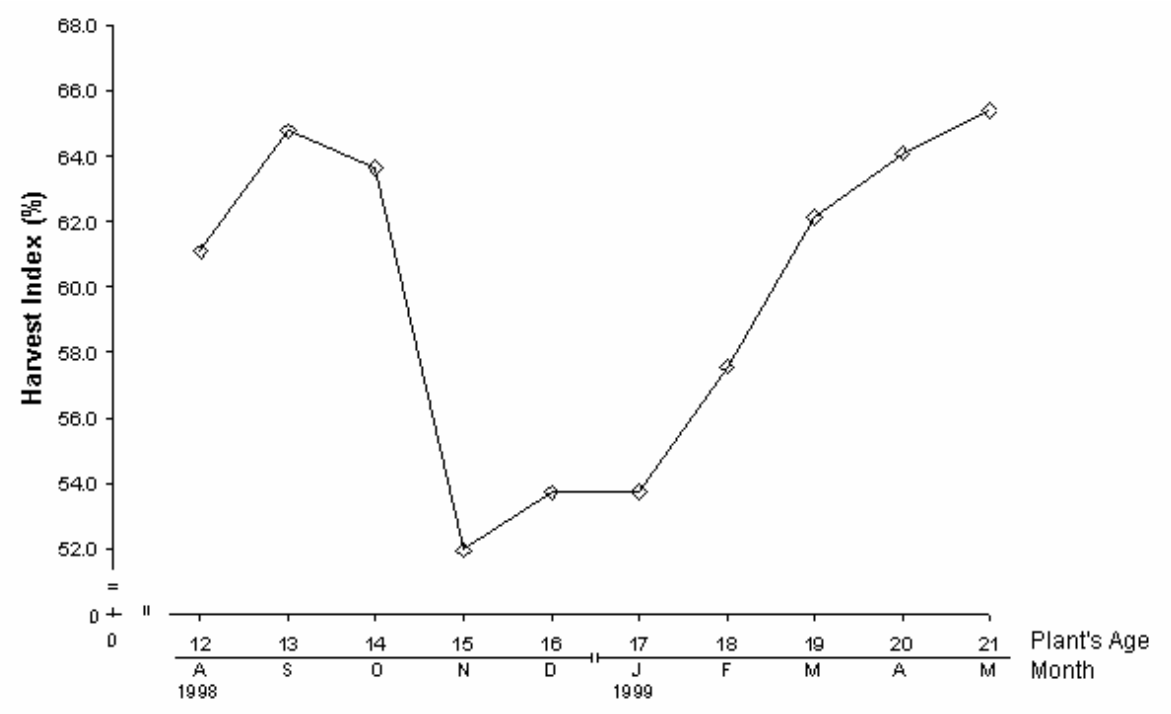

Figure 5 - Mean harvest index values based on dry matter (\%) of three cassava cultivars in 10 harvest times, during the second vegetative cycle. Araruna, PR, 1998/99.

The presentation of the harvest index based on dry matter, by plotting the dry storage root yield data in contrast to the total dry matter yield data was a simple and useful method developed by Boerboom (1978) to define the dry matter distribution in the cassava plant. The author assumed that assimilate partition in cassava followed a constant ratio throughout the plants life, a fact that was not confirmed by the data in Fig. 5. According to Keating et al. (1982), this was true for the tropical regions but for the high latitude regions, such as that where the present study was carried out $\left(23^{\circ} 55^{\prime} \mathrm{S}\right)$, the partition rates underwent high seasonal influences and tended to decrease with 
longer light periods, high temperatures and high relative humidity which were generally associated to high leaf area indexes.

Thus, the predominant climatic conditions in the region of Araruna and their seasonal variations seemed to have conditioned variations on the estimates of the partition rates to the storage roots of the cassava plants so that a higher proportion of carbohydrates was allocated to these storage roots in the periods of lower vegetative growth rates of the plants (Keating et al., 1982; Hobman et al., 1987 and Hammer et al., 1987).

\section{ACKNOWLEDGEMENTS}

The authors would like to thank Capes, CNPq, Araucaria Foundation and Pinduca Indústria Alimentícia Ltda for funding this project.

\section{RESUMO}

Com o objetivo de uma melhor compreensão da relação entre a produtividade total de massa seca e a proporção de alocação desta nas raízes tuberosas em plantas de mandioca, foi conduzido no município de Araruna-PR, um experimento em delineamento de blocos casualizados, em esquema de parcelas subdivididas com quatro repetições. Nas parcelas foram dispostas três cultivares (Mico, IAC 13 e IAC 14), e nas subparcelas dez épocas de colheita mensais, a partir do início do segundo ciclo vegetativo das plantas. As cultivares Mico e IAC 13 foram mais eficientes do que a IAC $14 \mathrm{em}$ alocar massa seca nas raízes tuberosas, ao passo que esta última alocou maior proporção de massa seca em suas hastes. Em relação às épocas, os menores índices de colheita ocorreram em períodos de mais intenso crescimento vegetativo das plantas, ao passo que a maior proporção de carboidratos foi alocada nas raízes tuberosas em períodos de baixo crescimento vegetativo.

\section{REFERENCES}

Abam (2006), Associação Brasileira dos Produtores de Amido de Mandioca. Avaiable in http://www.abam.com.br/adm/not.php?id=65. Accessed in June $25^{\text {th }} 2006$.

Alves, A. A. C. (2002), Cassava botany and physiology. In-Cassava: biology, production and utilization, ed.
R.J. Hillocks; J.M. Thresh and A.C. Bellotti. Cabi Publishing, UK, pp.67-89.

Banzatto, D. A. and Kronka, S. N. (1995), Experimentação agrícola. 3.ed., FUNEP, Jaboticabal

Boerboon, B. W. J. (1978), A model of dry matter distribution in cassava (Manihot esculenta Crantz). Netherlands Journal of Agricultural Science, 26, $267-$ 277.

Cardoso, C. E. L. and Souza, J. S. (2002), Importância, potencialidades e perspectivas do cultivo da mandioca na América Latina. In-Agricultura: tuberosas amiláceas Latino Americanas - Cultura de tuberosas amiláceas Latino Americanas, ed. Cereda, M. P. v.II. Fundação Cargill, São Paulo, pp.29-47.

Cereda, M. P. (2002), Importância das tuberosas tropicais. In-Agricultura: tuberosas amiláceas Latino Americanas - Cultura de tuberosas amiláceas Latino Americanas, ed. Cereda, M. P. v.II. Fundação Cargill, São Paulo, pp.13-25.

Cock, J. H.; Franklin, D.; Sandoval, G. and Juri, P. (1979), The ideal cassava plant for maximum yield. Crop Science, 19, 271-279.

Conceição, A. J. (1981), A mandioca. 3. ed., Nobel, São Paulo.

Doreto, M. (1993), Distribuição da cultura da mandioca no Paraná nos anos 80. Iapar, Londrina (Informe de Pesquisa, 102).

Embrapa (1999), Sistema Brasileiro de Classificação de Solo. Embrapa-CNPS, Rio de Janeiro.

Godoy, H.; Correia, A. R. and Santos, D. (1976), Clima do Paraná: manual agropecuário para o Paraná. Iapar, Londrina.

Hammer, G. L.; Hobman, F. R. and Shepherd, R. K. (1987), Effects of planting time and harvest age on cassava (Manihot esculenta) in Northern Australia. I. Crop growth and yield in moist environments. Experimental Agriculture, 23(4), 401-414.

Hobman, F. R.; Hammer, G. L. and Shepherd, R. K. (1987), Effects of planting time and harvest age on cassava (Manihot esculenta) in northern Australia. II. Crop growth and yield in a sazonally-dry environment. Experimental Agriculture, 23(4), 415424.

Keating, B.A.; Evenson, J. P. and Fukai, S. (1982), Environmental effects on growth and development of cassava (Manihot esculenta Crantz.). III. Assimilate distribution and storage organ yield. Field Crops Research, 5, 293-303.

Kvitschal, M. V.; Vidigal Filho, P. S.; Scapim, C. A.; Gonçalves-Vidigal, M. C.; Pequeno, M. G.; Sagrilo, E. and Rimoldi, F. (2006), Evaluation of phenotypic stability of cassava clones by AMMI analysis in northwestern Paraná state. Crop Breeding and Applied Biotechnology, 6 (3), 236-241.

Kvitschal, M. V.; Vidigal Filho, P. S.; Pequeno, M. G.; Sagrilo, E.; Brumati, C. C.; Manzotti, M. and Bevilaqua, G. (2003), Avaliação de clones de mandioca (Manihot esculenta, Crantz) para indústria na região 
Noroeste do estado do Paraná, Acta ScientiarumAgronomy, 25(2), 299-304.

Olsen, K. M. and Schaal, B. A. (1999), Evidence on the origin of cassava: Phylogeography of Manihot esculenta. Proceedings of the National Academy of Science, 96, 5586-5591.

Rimoldi, F.; Vidigal Filho, P. S.; Scapim, C. A. and Gonçalves-Vidigal, M. C. (2003), Avaliação de cultivares de mandioca nos municípios de Maringá e Rolândia, no Estado do Paraná. Acta ScientiarumAgronomy, 25(2), 459-465.

Rimoldi, F.; Vidigal Filho, P. S.; Gonçalves-Vidigal, M. C.; Clemente, E.; Pequeno, M. G.; Miranda, L.; Kvitschal, M. V. (2006). Produtividade, composição química e tempo de cozimento de cultivares de mandioca-de-mesa coletadas no Estado do Paraná. Acta Scientiarum- Agronomy, 28(1), 63-69.

Sagrilo, E.; Vidigal Filho, P. S.; Pequeno, M. G.; Scapim, C. A.; Gonçalves Vidigal, M. C.; Maia, R. R. and Kvitschal, M. V. (2002), Efeito da época de colheita no crescimento vegetativo, na produtividade e na qualidade de raízes de três cultivares de mandioca. Bragantia, 61(2), 115-125.

Sagrilo, E.; Vidigal Filho, P.S.; Pequeno, M.G.; Scapim, C.A.; Gonçalves Vidigal, M.C.; Diniz, S.P.S.S.; Modesto, E.C.; Kvitschal, M.V. (2003), Effect of harvest period on the quality of storage roots and protein content of the leaves in five cassava cultivars (Manihot esculenta, Crantz). Brazilian Archives of Biology and Technology, 46(2), 295-305. Sagrilo, E.; Vidigal Filho, P.S.; Pequeno, M.G.; Gonçalves Vidigal, M.C.; Scapin, C.A.; Kvitschal, M.V.; Maia, R.R.; Rimoldi, F. (2006) Effect of harvest period on foliage production and dry matter distribution in five cassava cultivars during the second plant cycle. Brazilian Archives of Biology and Technology, 49(6), 1007-1018.

Sales Filho, J. B. (1980), Distribuição de carboidratos em plantas de mandioca (Manihot esculenta, Crantz) e o efeito do teor de reservas, na brotação e enraizamento de estacas de três posições do caule. M.Sc. Dissertation, Universidade Federal de Viçosa, Viçosa, Brazil.

Silva, D. J. (1981), Análise de alimentos: métodos químicos e biológicos. UFV - Imprensa Universitária, Viçosa.

Souza, A. B. and Fasiaben, M. C. R. (1986), Competição de cultivares de mandioca conduzida em uma pequena propriedade no município de Rio Azul, Paraná. Revista Brasileira de Mandioca, 5, 99-104.

Távora, F. J. A. F. and Barbosa Filho, M. (1994), Antecipação de plantio, com irrigação suplementar, no crescimento e produção de mandioca. Pesquisa Agropecuária Brasileira, 29(12), 1915-1926.

Veltkamp, H. J. (1985), Physiological causes of yield variation in cassava (Manihot esculenta Crantz). $\mathrm{PhD}$ Thesis, Agriculture University, Wageningen, Netherlands.

Vidigal Filho, P. S.; Pequeno, M. G.; Scapim, C. A.; Gonçalves-Vidigal, M. C.; Maia, R. R.; Sagrilo, E.; Simon, G. and Lima, R. S. (2000), Avaliação de cultivares de mandioca na região Noroeste do Paraná. Bragantia, 59(1), 69-75. 
PÁGINA

EM

BRANCO 